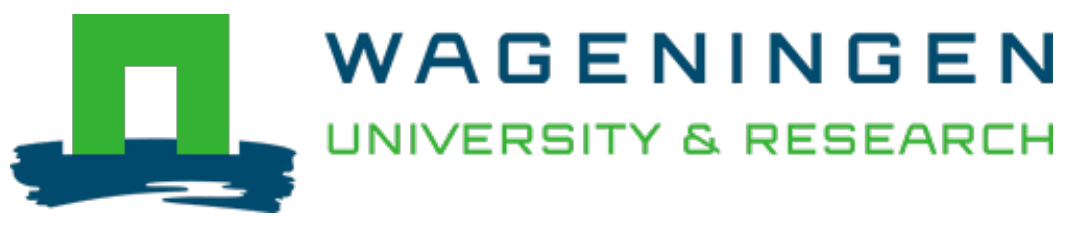

\title{
Ecology of controlled soyabean acidification for tempeh manufacture
}

Food Microbiology

Nout, M.J.R.; Dreu, M.A.; Zuurbier, A.M.; Bonants-van Laarhoven, T.M.G.

https://doi.org/10.1016/0740-0020(87)90032-3

This publication is made publicly available in the institutional repository of Wageningen University and Research, under the terms of article $25 \mathrm{fa}$ of the Dutch Copyright Act, also known as the Amendment Taverne. This has been done with explicit consent by the author.

Article $25 \mathrm{fa}$ states that the author of a short scientific work funded either wholly or partially by Dutch public funds is entitled to make that work publicly available for no consideration following a reasonable period of time after the work was first published, provided that clear reference is made to the source of the first publication of the work.

This publication is distributed under The Association of Universities in the Netherlands (VSNU) 'Article $25 \mathrm{fa}$ implementation' project. In this project research outputs of researchers employed by Dutch Universities that comply with the legal requirements of Article $25 \mathrm{fa}$ of the Dutch Copyright Act are distributed online and free of cost or other barriers in institutional repositories. Research outputs are distributed six months after their first online publication in the original published version and with proper attribution to the source of the original publication.

You are permitted to download and use the publication for personal purposes. All rights remain with the author(s) and / or copyright owner(s) of this work. Any use of the publication or parts of it other than authorised under article $25 \mathrm{fa}$ of the Dutch Copyright act is prohibited. Wageningen University \& Research and the author(s) of this publication shall not be held responsible or liable for any damages resulting from your (re)use of this publication.

For questions regarding the public availability of this publication please contact openscience.library@,wur.nl 


\title{
Ecology of controlled soyabean acidification for tempe manufacture
}

\author{
M. J. R. Nout, M. A. de Dreu, A. M. Zuurbier and T. M. G. \\ Bonants-van Laarhoven
}

Department of Food Science, Agricultural University, De Dreijen 12, 6703 BC Wageningen, The Netherlands

Received 7 February 1987

\begin{abstract}
During the traditional Indonesian tempe manufacturing process, spontaneous and uncontrolled fermentations of soyabeans take place during the soaking stage prior to fungal fermentation. Often, such fermentations result in an acidification of the beans. A comparison of industrial tempe processes suggested that fermentative acidification during soaking inhibits the multiplication of spoilage causing bacilli. The acidification during soaking could be controlled by recycling part of the soak water from $a$ previous batch as an inoculum, resulting in a soak water $p H$ of 4.1-4.9 depending on soaking temperature and recycling rate. Soaks at $19^{\circ} \mathrm{C}$ and $25^{\circ} \mathrm{C}$ were dominated by Lactobacillus plantarum. Isolates of L. plantarum added as an inoculum to freshly started soaks were able to acidify the beans to $\mathrm{pH} \leq 4.30$ yielding tempe of good quality in which bacilli and Enterobacteriaceae could not be detected. Yeasts, notably Saccharomyces dairensis, present in soaks at $19^{\circ} \mathrm{C}$ and $25^{\circ} \mathrm{C}$, did not contribute to the acidification and could not prevent early spoilage of tempe. Pediococcus spp. dominated soaks at $37^{\circ} \mathrm{C}$, and though able to acidify soyabeans, inhibited the growth of Rhizopus oligosporus; hence no tempe could be formed. Our findings indicate that $a$ simple recycling process can result in predictable acidification during soaking of soyabeans, contributing to the shelf-life and safety of tempe.
\end{abstract}

\section{Introduction}

Soyabean tempe (Ko and Hesseltine 1979 ) is a protein-rich fermented food of Indonesian origin obtained by a 2 -stage fermentation process, i.e. a pre-fermentation stage during the preparatory soaking of soyabeans, followed by a fungal solidstate fermentation stage, usually with $R$ hizopus oligosporus.

Although tempe is generally described as a fungal fermented food, it has been shown to contain a significant accompanying microflora of bacteria and

* To whom all correspondence should be addressed.

$0740-0020 / 87 / 020165+08 \$ 02.00 / 0$ yeasts (Samson et al. 1987).

Among the factors determining the shelf-life and consumer safety of tempe, the composition and activity of this accompanying flora may be expected to play an important role. Figure 1 presents a flow-sheet of tempe manufacturing operations including major environmental factors which may influence the microbiological composition of the final product.

This paper deals with the control of the pre-fermentation soaking stage of soyabeans, but might be applicable to fermentations of other vegetable material as well. The traditional procedure of soaking the beans in fresh 


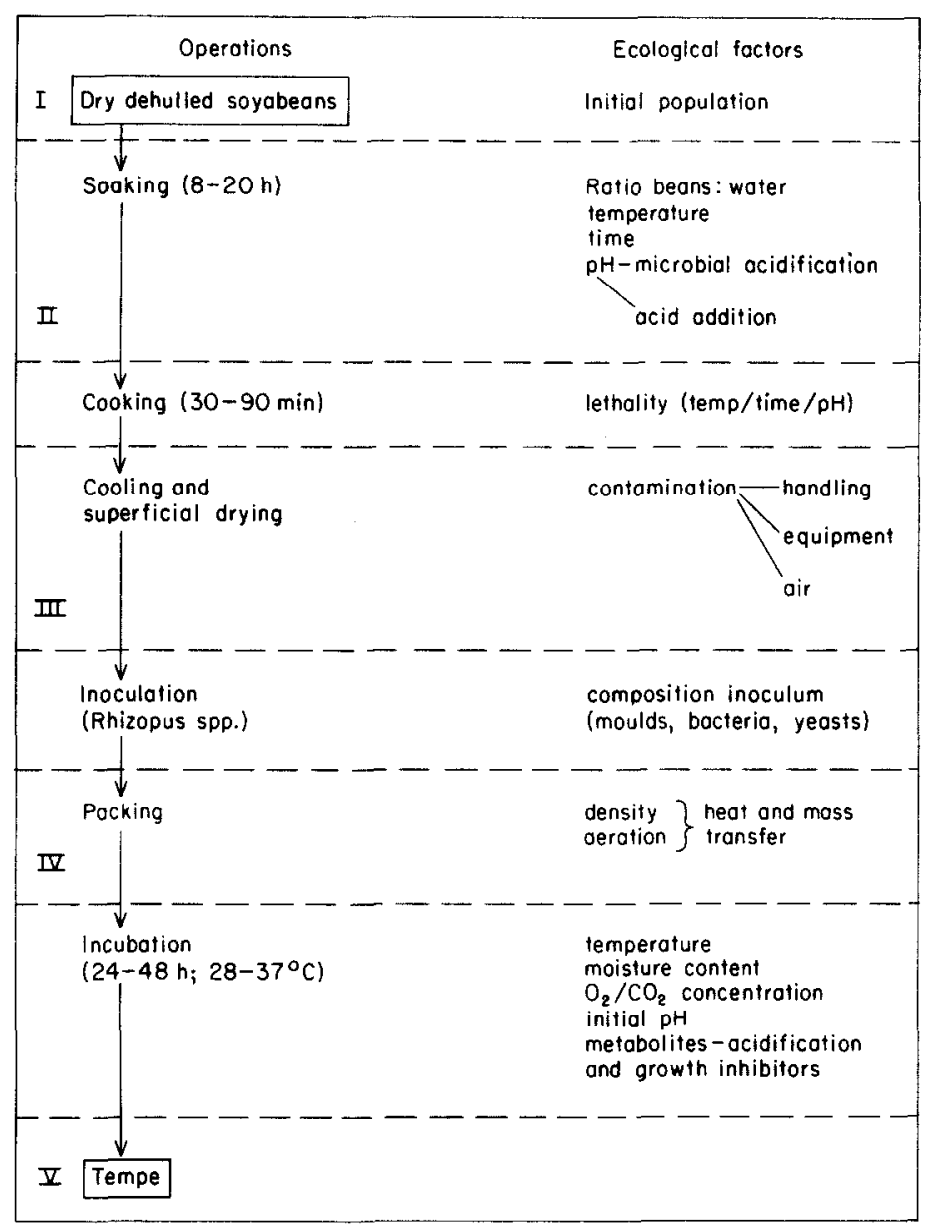

Fig. 1. Manufacture of tempe and factors influencing its microbiological composition. I-V: processing stages indicated in Figure 3.

water overnight at $25^{\circ} \mathrm{C}-30^{\circ} \mathrm{C}$ results in spontaneous fermentations. Whereas these uncontrolled fermentations may achieve acidification to approx $\mathrm{pH} 4.5$ (Ko and Hesseltine 1979), we found that this souring may be delayed or remain absent in an unpredictable way.

It was probably for this reason that it has been recommended earlier (Steinkraus et al. 1965) to soak the beans in e.g. dilute lactic acid in order to obtain $\mathrm{pH}$ values of 4.8-5.0 prior to the fungal fermentation stage, thereby preventing the growth of spoilage causing microorganisms.

Little evidence for this inhibition in tempe made from acidified beans has been published; on the other hand, it was reported (Tanaka et al. 1985) that several pathogenic bacteria could grow well during the manufacture of tempe from unacidified soyabeans.

Tempe technology meets an increasing interest in developing countries as a small-scale method to derive nutritious food from locally available legumes and cereals. In such circumstances, $\mathrm{pH}$ adjustment of beans by acid addition would necessitate food-grade chemicals and $\mathrm{pH}$ control.

Alternatively, we investigated the possibility of optimizing and stabiliz- 
ing the fermentative acidification of soyabeans by using part of the soak water as an inoculum.

\section{Methods}

\section{Tempe manufacture}

Dry abrasion-dehulled yellow var. soyabeans $(1 \mathrm{~kg}) \mathrm{kept}$ at $-20^{\circ} \mathrm{C}$ to avoid insect infestation, were rinsed twice with 111 tapwater of $45^{\circ} \mathrm{C}$, drained and soaked either (a) for spontaneous fermentation in 31 tapwater of $45^{\circ} \mathrm{C}$ in an incubator at $25^{\circ} \mathrm{C}$ for $24 \mathrm{~h}$, or (b) using the recycling procedure (below).

After draining the soak water, the beans were rinsed twice with $11 \mathrm{l}$ tapwater of $25^{\circ} \mathrm{C}$, brought to the boil in 31 fresh tapwater and boiled for $20 \mathrm{~min}$. In order to simulate manufacturing practice, no attempts were made to work under aseptic conditions, thereby allowing the cross-contamination of cooked beans. To this effect, after draining and discarding the boiling water, the hot beans were immediately spread in a layer of approx $1 \mathrm{~cm}$ thickness on a wire-mesh and turned twice to facilitate the evaporation of adhering water. After approx 20 mins the beans were hand-dry and cooled to $20^{\circ}-25^{\circ} \mathrm{C}$, and were transferred into a container and mixed with $10 \mathrm{ml}$ spore suspension. This spore suspension was obtained by adding $9 \mathrm{ml}$ peptone saline each to 2 malt extract agar slant cultures of Rhizopus oligosporus NRRL 5905 which had been incubated at $30^{\circ} \mathrm{C}$ for 1 week, followed by scraping off the spores.

After inoculation, $30-50 \mathrm{~g}$ beans were stiffly packed into a $9 \mathrm{~cm}$ diam Petri dish with 4-5 perforations of $0.5 \mathrm{~mm}$ diam. in bottom and lid and incubated at $30^{\circ} \mathrm{C}$ for $45 \mathrm{~h}$, yielding fresh tempe.

The assessment of tempe quality for accetability was based upon exterior colour, texture, odour and evenness of mycelial penetration into the centre of the cake, as judged by an expert panel in accordance with guidelines for good quality (Nout et al. 1985).

\section{Recycling procedure}

Soaking of soyabeans with recycling was carried out as in Figure 2, at soaking temp (t) $14^{\circ}, 19^{\circ}, 25^{\circ}, 30^{\circ}, 37^{\circ}$, and $45^{\circ} \mathrm{C}$. Recycling rates (x) of 1 and 0.1 were used, so that $25 \%$ resp. $2.5 \%$ of a soak consisted of soak water from the previous batch. Usually, recyclings

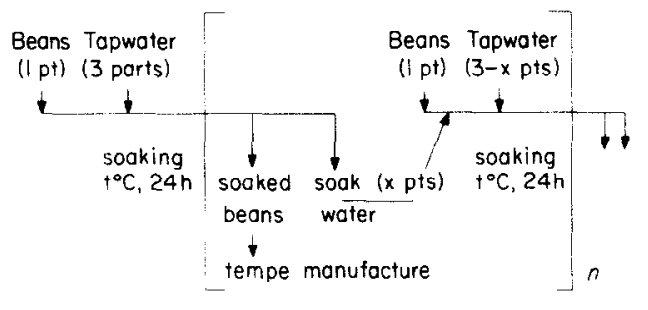

Fig. 2. Principle of soaking process with soak water recycling.

were carried out every $24 \mathrm{~h}$. Occasionally, soak water was kept at $4^{\circ} \mathrm{C}$ until used again as an inoculum.

\section{Microbiological analysis}

The following media were used: total viable count: plate count agar (PCA); total count of bacteria: PCA with 200 ppm cycloheximide (acti-dione); Enterobacteriaceae: violet red bile glucose agar (VRBG) with overlay; lactic acid bacteria: Rogosa agar with overlay for selective counting, or MRS agar with overlay for samples containing only lactic acid bacteria. For identification of microbial isolates, $\sqrt{n}$ or at least 10 colonies were isolated from appropriate counting plates, and purified on PCA (bacteria), MRS agar (lactic acid bacteria), or malt extract agar (yeasts and moulds). Identification followed established descriptions of bacteria (Buchanan and Gibbons 1974), yeasts (Kreger-van Rij 1984) and moulds (Samson et al. 1984). In addition, descriptions of lactobacilli (Rogosa and Sharpe 1959) and pediococci (Tanasupawat and Daengsubha 1983) were used.

\section{Results and Discussion}

During the investigation of industrial tempe manufacturing processes, we observed that fermentative acidification during the soak influenced the microbiological composition in later processing stages and in the final product.

Figure 3 summarizes different industrial processes: (A) where the soak was started with addition of some soak water from a previous batch; and (B) where each soak was started with fresh water in a cleaned vessel. 


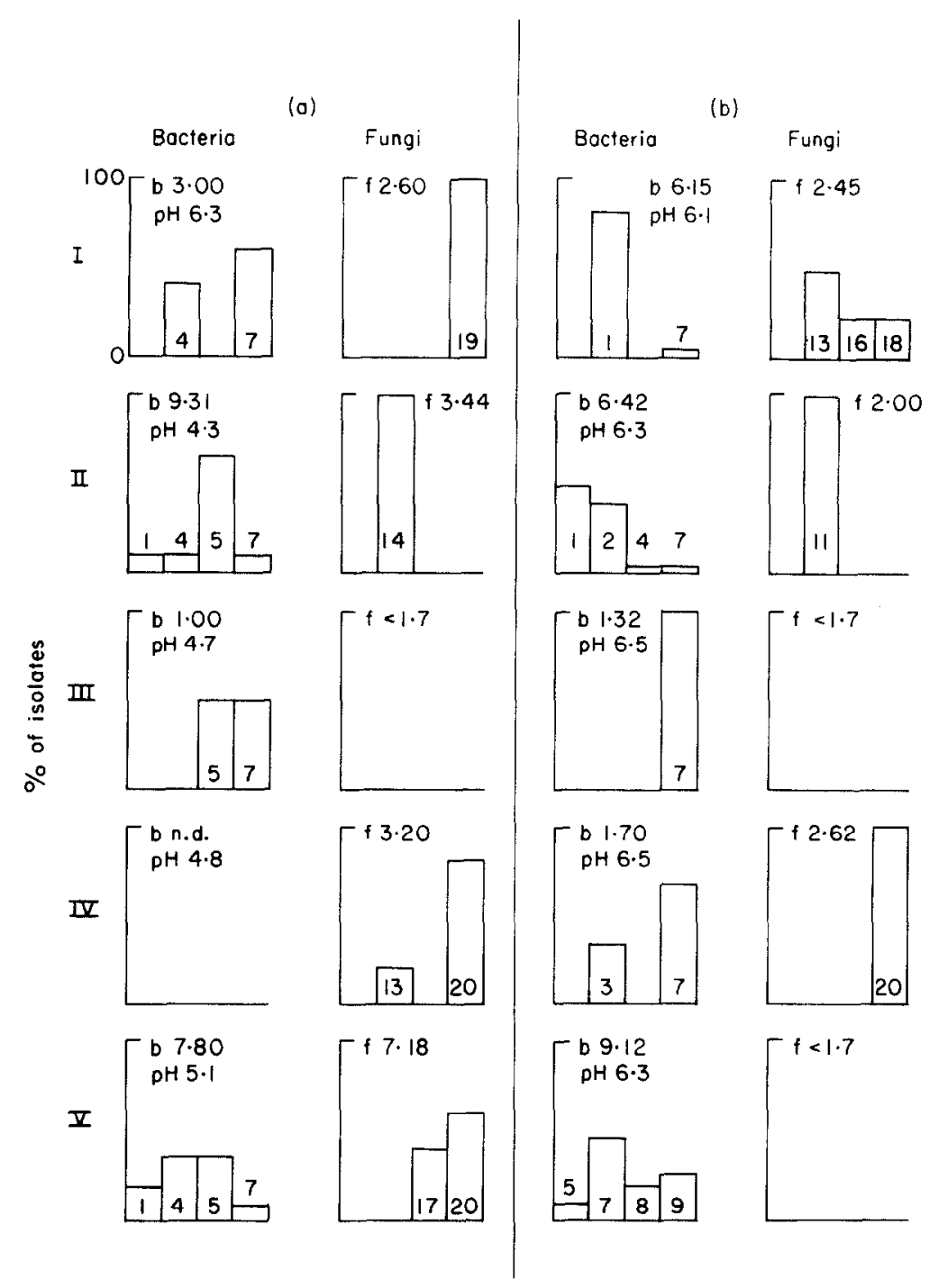

Fig. 3. Microbiological composition and $\mathrm{pH}$ during industrial tempe processes. (a): process with inoculated soak; (b): process with soak for spontaneous fermentation. I-V: processing stages indicated in Fig. $1 ; b=$ bacteria $\log \mathrm{cfu} / \mathrm{g} ; \mathrm{f}=$ yeasts and moulds $\log \mathrm{cfu} / \mathrm{g} ; \mathrm{n} . \mathrm{d} .=$ not determined; 1 = Enterobacteriaceae; 2 =Chromo-/Flavobacterium; $3=$ Pseudomonas; $4=$ unidentified Gram-negative rodshaped bacteria, $5=$ Lactobacillus $; 6=$ Aero-/Streptococcus, 7 = Bacillus; 8 = Micrococcus; 9 = Staphylococcus $; 10=$ Candida; $11=$ Cryptococcus; $12=$ Hansenula $; 13=$ Rhodotorula $14=$ Saccharomyces $; 15=$ Torulaspora $; 16=$ Cladosporium $; 17$ = Geotrichum; $18=$ Mucor $; 19=$ Penicillium $; 20=$ Rhizopus.

Process A was characterized by a significant acidification (soak water $\mathrm{pH}$ 4.3) dominated by lactobacilli, whereas only slight or no acidification took place in process $B$ with a soak dominated by Gram-negative bacteria, mainly Enterobacteriaceae.
In both processes, yeasts were present in the soak water as well.

After cooking, the beans are usually cross-contaminated through handling, equipment, etc. Whereas such contaminations could be demonstrated in both processes, undesirable outgrowth of ba- 
cilli was significantly reduced during process A as compared to process B.

In laboratory experiments, the influence of the parameters $x$ (recycling rate) and $n$ (number of recyclings) on the microbiology of the soak and later stages of the tempe process were investigated at various soak water temperatures using the recycling soak procedure shown in Fig. 2.

At all tested temperatures, repeated recyclings resulted in a steady state acidification as illustrated by Fig. 4. The average final $\mathrm{pH}$ values of the soak water obtained during such steady state conditions are presented in Table 1.

With spontaneous soaks (Fig. 4: $n=0$ ) no acidification was achieved. This is a situation comparable with the slight acidification observed in process B (Fig. 3). At $19^{\circ} \mathrm{C}$, a significant and predictable acidification was obtained after 4 recy- clings. The extent of acidification depended on the soak water temperature and the recycling rate; as shown in Table 1 , $30^{\circ}-37^{\circ} \mathrm{C}$ yielded the lowest $\mathrm{pH}$ values.

Due to the dilution effect, the low recycling rate $(x=0 \cdot 1)$ caused a greater amplitude of the $\mathrm{pH}$ fluctuation as compared to the higher rate $(x=1)$ as shown in the inset of Fig. 4. Small differences were observed between the final $\mathrm{pH}$ values obtained at both recycling rates (Table 1) which, if at all significant, may be attributed to the combined effects of temperature dependent growth rates and dilution (recycling) rate.

Our investigation of industrial soaks had identified lactic acid bacteria, $E n$ terobacteriaceae and yeasts as the most likely to dominate the soak water flora. The presence of these groups of microorganisms was monitored at different temperatures, recycling rates and num-

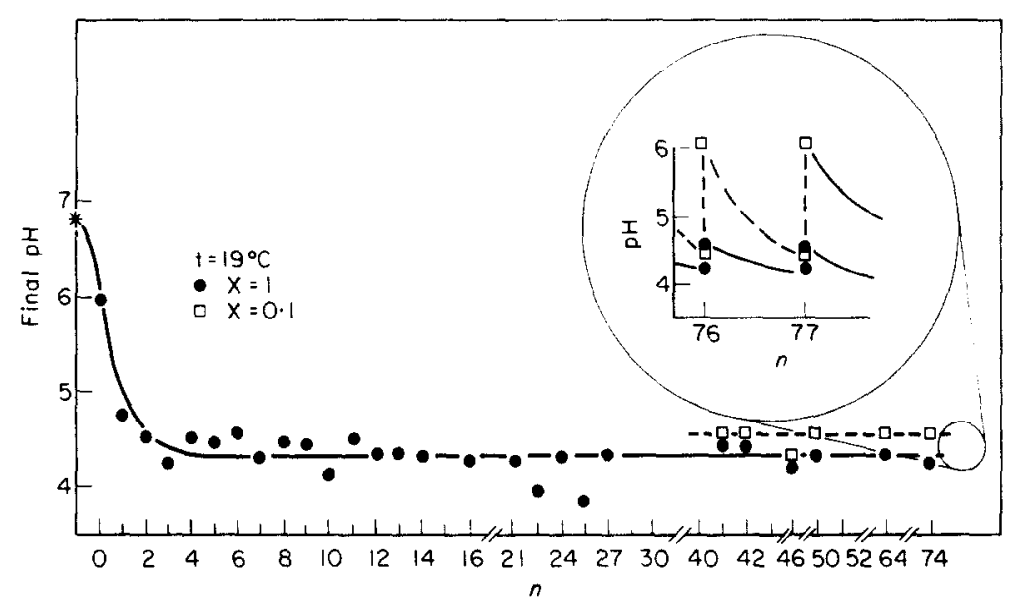

Fig. 4. Influence of $n$ (no. of recyclings) on the final soak water pH. Inset: effect of $x$ (recycling rate) on soak water $\mathrm{pH}$ fluctuation. ${ }^{*}=\mathrm{pH}$ at start of first soak.

Table 1. Influence of $t$ (soak water temp) and $x$ (recycling rate) on final soak water $\mathrm{pH}$ (stabilized situation).

\begin{tabular}{lcccccc}
\hline $\mathrm{t}\left({ }^{\circ} \mathrm{C}\right)$ & 14 & 19 & 25 & 30 & 37 & 45 \\
\hline $\mathrm{x}=1$ & 4.92 & 4.38 & 4.20 & 4.13 & $4 \cdot 23$ & 4.27 \\
$\mathrm{x}=0.1$ & & 4.53 & $4 \cdot 20$ & & 4.12 & \\
\hline
\end{tabular}




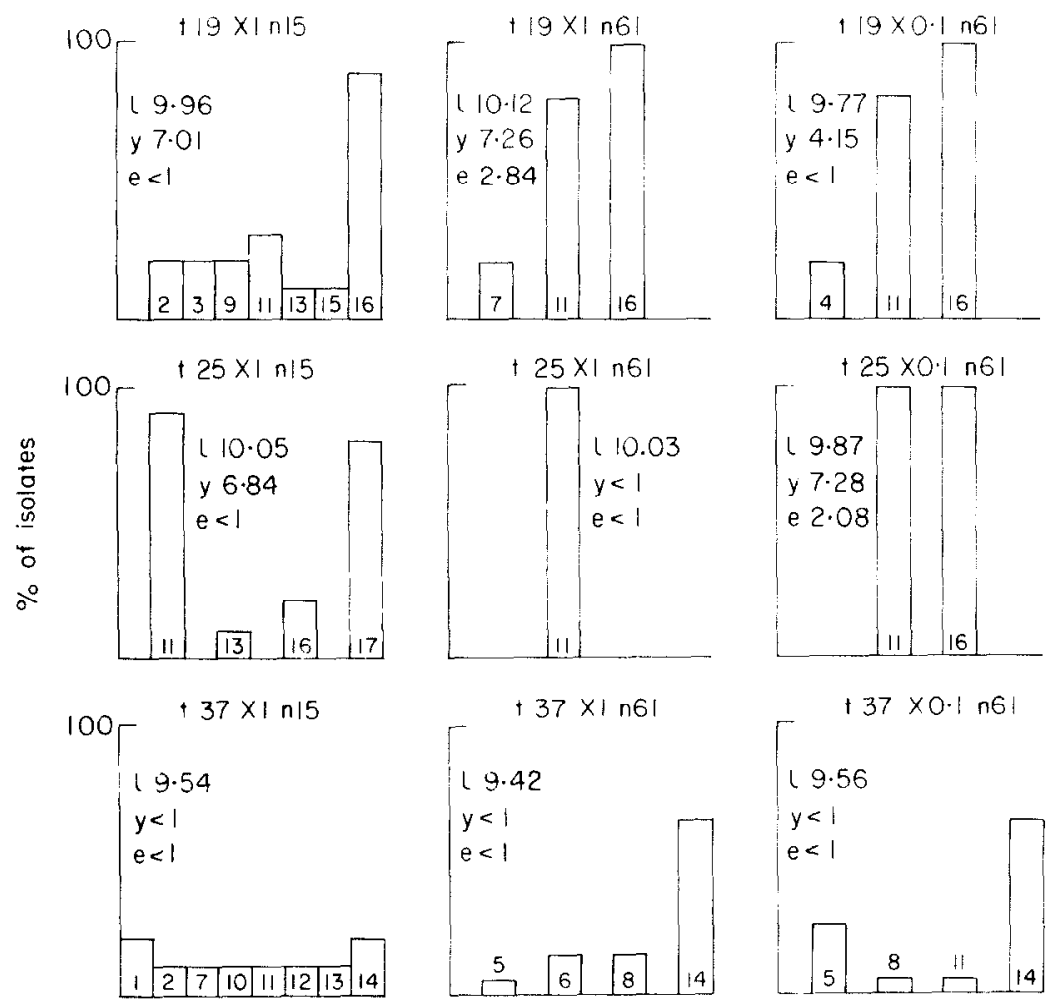

Fig. 5. Influence of $t$ (soak water temp), $x$ (recycling rate) and $\mathbf{n}$ (no. of recyclings) on the selection of soak water microflora. 1 = lactic acid bacteria $(\log \mathrm{cfu} / \mathrm{g}) ; \mathrm{y}=$ yeasts $(\log \mathrm{cfu} / \mathrm{g}) ; \mathrm{e}=$ Enterobacteriaceae ( $\log \mathrm{cfu} / \mathrm{g}) ; 1=$ Leuconostoc mesenteroides; $2=$ Lactobacillus brevis; $3=L$. buchneri; $4=L$. coprophilus; $5=L$. fermentum; $6=$ L. acidophilus $; 7=L$. casei $; 8=L$. case $i$ ssp. alactosus $; 9=L$. case $i$ ssp. pseudoplantarum; $10=L$. coryniformis; $11=L$. plantarum; 12 = L. salivarius; $13=$ Streptococcus spp.; $14=$ Pediococcus spp., $15=$ Candida sake; $16=$ Saccharomyces dairensis; $17=$ yeast $\mathrm{sp}$.

bers of recyclings and is presented in Fig. 5.

In similarity with the industrial inoculated soak (Fig. 3, process A), Enterobacteriaceae either formed an insignificant minority or were absent in the acidified soak water.

Although the acidification reached a steady state after 4 recyclings as judged on the basis of final soak water pH, Fig. 5 shows that the process of microbial selection is considerably slower. From the diversity of species detected after 15 recyclings, $50 \%$ or less were recovered after 61 recyclings together with some species that had not been found earlier. Similar long-term natural microbial selection processes were observed during the maturation of sourdough starters (Nout and Creemers-Molenaar 1987).

In addition to the progressive number of recyclings, the combined effect of temperature, dilution rate and $\mathrm{pH}$ fluctuations (the latter both determined by the recycling rate) played a role during the microbial selection. Of the lactic acid bacteria, Lactobacillus plantarum tended to dominate at $25^{\circ} \mathrm{C}$ and at $19^{\circ} \mathrm{C}$. At $37^{\circ} \mathrm{C}$ however, Pediococcus spp. formed the majority. Yeasts, mainly Saccharomyces dairensis grew well at $19^{\circ} \mathrm{C}$ and remained a significant component of the microflora at recycling rate $\mathbf{x}=1$. However, their lower count at $\mathrm{x}=0.1$ suggests that their growth rate at this temperature/pH combination might not 
Table 2. Influence of soaks inoculated with Lactobacillus plantarum and Saccharomyces dairensis on characteristics and microbiological composition (log cfu/g) of tempe.

\begin{tabular}{|c|c|c|c|c|c|c|}
\hline & \multicolumn{2}{|c|}{$\begin{array}{c}\text { Control } \\
\text { (spontaneous) }\end{array}$} & \multicolumn{4}{|c|}{ 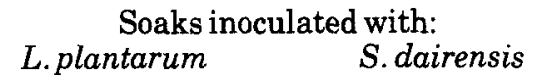 } \\
\hline & Soak & Tempe & Soak & Tempe & Soak & Tempe \\
\hline Acceptability & & $+-a$ & & + & & +- \\
\hline $\mathrm{pH}$ & $5 \cdot 55$ & $6 \cdot 27$ & $4 \cdot 30$ & 6.08 & $6 \cdot 00$ & $6 \cdot 33$ \\
\hline Enterobacteriaceae & 8.38 & $8 \cdot 13$ & $2 \cdot 48$ & $<1.7$ & $7 \cdot 65$ & $8 \cdot 00$ \\
\hline Bacillus spp. & n.d. ${ }^{b}$ & 8.07 & n.d. & $<1.7$ & n.d. & 8.50 \\
\hline Lactic acid bacteria & 8.56 & 7.01 & 9.99 & $6 \cdot 50$ & $6 \cdot 55$ & 8.90 \\
\hline Yeasts & n.d. & n.d. & n.d. & n.d. & $6 \cdot 83$ & $6 \cdot 93$ \\
\hline
\end{tabular}

$a+=$ excellent, $+-=$ fair;

$\mathrm{b}$ n.d. $=$ not determined.

suffice to prevent a wash-out at this dilution rate in the long run.

At $25^{\circ} \mathrm{C}, S$. dairensis and other yeasts present at $n=15$, had disappeared at $n=$ 61 with $\mathrm{x}=1$ but remained at $\mathrm{x}=0 \cdot 1$. Since the growth rate of $S$. dairensis at $25^{\circ} \mathrm{C}$ appears adequate to cope with the dilution rate at $x=0.1$, we suspect that the low $\mathrm{pH}$ becomes a limiting factor at this temperature. The larger $\mathrm{pH}$ fluctuations at $\mathrm{x}=0.1 \mathrm{might}$ still facilitate growth, in contrast to the continuously low $\mathrm{pH}$ levels at $\mathrm{x}=1$.

The effect of the micro-organisms dominating the long-term soaks, L. plantarum, Pediococcus sp. and S. dairensis on the quality and microbiological com. position of tempe, was investigated using the process aimed at simulating industrial conditions.

Pediococcus sp. inhibited the growth of $R$. oligosporus to such an extent that no tempe could be obtained. The nature of this inhibition, which might be similar to that observed earlier (Steinkraus et al. 1965) with Lactobacillus brevis inoculated soaks, was not investigated.

The effect of $L$. plantarum and $S$. dairensis is presented in Table 2. In the control process initiated by a soak for spontaneous fermentation, domination by Enterobacteriaceae and lactic acid bacteria was observed and some acidifi- cation occurred which was however not adequate to prevent the multiplication of Enterobacteriaceae and Bacillus spp. during the tempe fermentation. The final product was only of fair acceptability due to a musty off-odour.

Similar soaks inoculated at the start with $7 \mathrm{log} \mathrm{cfu} / \mathrm{g}$ of a L. plantarum isolate achieved soak water with $\mathrm{pH} 4.3$ in which Enterobacteriaceae were present as a minority only. The final tempe was of excellent quality and did not contain detectable levels of Enterobacteriaceae or Bacillus spp.

On the other hand, soaks inoculated with $6 \mathrm{log} \mathrm{cfu} / \mathrm{g}$ of a $S$. dairensis isolate failed to acidify despite good yeast growth, and contained numbers of Enterobacteriaceae similar to the control. The obtained tempe was of fair quality mainly because of its disagreeable smell.

It is concluded that a simple recycling process can result in a predictable acidification during the soaking of soyabeans. Domination of $L$. plantarum during the soaking stage followed by their outgrowth during the tempe fermentation tend to contribute to the acceptability and safety of the final product by suppressing Enterobacteriaceae, Baccillus and possibly other $\mathrm{pH}$-sensitive microorganisms. 


\section{References}

Baggerman, W. I. (1981) A modified rose bengal medium for the enumeration of yeasts and moulds from foods. Eur. J. Appl. Microbiol. 12, 242-247.

Buchanan, R. E. and Gibbons, N. E. (Eds). (1974) Bergey's manual of determinative bacteriology, 8th edn. Baltimore, The Williams \& Wilkins Co.

Ko, S. D. and Hesseltine, C. W. (1979) Tempe and related foods. In Economic Microbiology, vol. 4, Microbiol Biomass (Ed. Rose, A. H.) pp. 115-140. London, Academic Press.

Kreger-van Rij, N. J. W. (1984) The Yeasts: a taxonomic study. 3rd rev. and enl. edn. Amsterdam, Elsevier.

Nout, M. J. R., Bonants-van Laarhoven, T. M. G., de Dreu, R. and Gerats, I. A. G. M. (1985) The influence of some process variables and storage conditions on the quality and shelf-life of soybean tempeh. Antonie van Leeuwenhoek, 51, 532-534.

Nout, M. J. R. and Creemers-Molenaar, T. (1987) Microbiological properties of some wheatmeal sourdough starters. Chemie Mikrobiol. Technol. Lebensmittel, 10, 162-167.

Rogosa, M. and Sharpe, M. E. (1959) An approach to the classification of the lactobacilli. $J$. Appl. Bacteriol. 22, 329-340.

Samson, R. A., Hoekstra, E. S. and van Oorschot, C. A. N. (1984) Introduction to food-borne fungi. Baarn, Centraalbureau voor Schimmelcultures.

Samson, R. A., van Kooij, J. A. and De Boer, E. (1987) Microbiological quality of commercial tempeh in The Netherlands. J. Food Protect. 50, 92-94.

Steinkraus, K. H., van Buren, J. P., Hackler, L. R. and Hand, D. B. (1965) A pilot-plant process for the production of dehydrated tempeh. Food Technol. 19, 63-68.

Tanaka, N., Kovats, S. K., Guggisberg, J. A., Meske, L. M. and Doyle, M. P. (1985) Evaluation of the microbiological safety of tempeh made from unacidified soyabeans. J. Food Protect. $48,438-441$.

Tanasupawat, S. W. and Daengsubha, W. (1983) Pediococcus species and related bacteria found in fermented foods and related materials in Thailand. J. Gen. Appl. Microbiol. 29, 487-506. 